\author{
N.T. Shogelova ${ }^{1}$, S.A. Sartin ${ }^{2 *}$ \\ ${ }^{1}$ International Educational Corporation (KazGASA campus), Almaty, Kazakhstan \\ ${ }^{2}$ North Kazakhstan University named after Manash Kozybayev, Petropavlovsk, Kazakhstan
}

Information about the authors:

Shogelova Nazym Tulegenovna - Master of Technical Sciences, assistant. Professors, International Educational Corporation (KazGASA campus), Almaty, Kazakhstan

https://orcid.org/0000-0002-5220-1459, e-mail: nazym-shogelova@mail.ru

Sartin Sergey Aleksandrovich - Candidate of Physical and Mathematical Sciences, Head of the Department of Physics, North Kazakhstan University named after Manash Kozybayev, Petropavlovsk, Kazakhstan

https://orcid.org/0000-0002-5637-3311, e-mail: sartin78@mail.ru

\title{
APPLICATION OF LANDSCAPE-GEOCHEMICAL APPROACH IN THE STUDY OF THE TERRITORY OF THE NORTH KAZAKHSTAN REGION
}

Annotation. The article discusses the issues of assessing the ecological condition of agricultural lands in the border territory of the North Kazakhstan region and identifying the necessary measures to optimize the existing structure of land use. The border area under study is located in the zone of dry-steppe and steppe landscapes, among which dry-steppe landscapes of relatively elevated plains predominate.

Keywords: landscape, North Kazakhstan region, landscape and ecological studies, dry steppe landscape, steppe landscape.

\section{Introduction}

The involvement of landscapes in the sphere of human activity is significantly ahead of the process of understanding it by science. Landscape studies actively studies new functions of landscapes. The landscape-geochemical approach to the scientific division of the territory is based primarily on the morphological parts of the landscape, its typological mapping and regional (zoning) study, classification, accounting for its internal and external relations.

The predominant type of soils in the North Kazakhstan region are chernozems. However, throughout the territory of the North Kazakhstan region, chernozems are heterogeneous and differ in geochemical characteristics. Consequently, the study of soils is impossible without in-depth comprehensive studies of the homogeneity and variability of soil and landscape conditions, naturally taking into account the influence of anthropogenic activity, which in turn introduces the greatest disturbances in the biological balance and biogenic circulation of matter during the transformation of the natural landscape. Therefore, when studying the soils of various landscapegeochemical areas, samples are taken both on the plowed and not plowed (virgin) parts of the territory.

Geochemical landscapes are different from each other. Each of them is characterized by the common features of relief, moisture, solar radiation, and as a consequence, the nature of vegetation and soil geochemical features. With the peculiarities of the manifestation of landscape heterogeneity, stability and changes in the course of 
biochemical and biophysical processes, it is necessary to strictly link the system of agriculture (agricultural specialization and land reclamation, agrotechnics) in each specific area and farm.

The development of the territory organization project should be preceded by a comprehensive comprehensive analysis based on the materials of landscape mapping and zoning. From landscape maps, schemes (grids) and maps of complex natural zoning, it is clear what the lands of certain morphological parts of the landscape are, what their landscape heterogeneity and potential agricultural opportunities for increasing production per unit area are. In other words, economic loads on the landscape must be regulated in accordance with its natural structure, to preserve the landscape-ecological balance in nature.

The ecological manifestation of degradation processes in the agricultural landscapes of the territory of the region is dehumification, which is expressed in a decrease in the content of humus, which entails a decrease in the reserves of biogenic elements in the soil, a violation of the balance of mineral and organic substances, a change in the structure of the soil and, as a consequence, the development of deflationary and erosive processes.

The landscapes of the North Kazakhstan Region belong to the forest-steppe and steppe types. They include areas whose allocation is based on the features of the geological structure, relief, soil and vegetation cover. In the landscape structure of the region, the forest-steppe type of landscape is decisive. This type is typical for the northern, western, eastern and central regions of the region, which is formed on the ancient loamy plains. In the forest-steppe type of landscape, we have identified localities, the dominant of which are the areas of hollow-hilly-mane plains, flat upland plains.

Another main type of landscape is steppe, which occupies a smaller part of the territory and is formed on the loamy plains of the southern regions of the region. This type is dominated by terrain.

The data obtained made it possible to determine for each administrative region of the North Kazakhstan region a probabilistic information measure of diversity (coefficient of landscape diversity) by K. Shannon. The results of the work for some districts of the region are presented in Table 1.

Table 1 - Coefficient of landscape diversity of administrative districts of North Kazakhstan region

\begin{tabular}{|l|c|}
\hline Name of the district & Coefficient of landscape diversity \\
\hline Akkayynsky (Soviet) & 3,68 \\
\hline Yesilsky (Leninsky, Moskovsky) & 4,44 \\
\hline Zhambylsky (Presnovsky, Zhambylsky) & 4,06 \\
\hline Kyzylzharsky (Bishkul, Sokolovsky) & 3,37 \\
\hline M.Zhumabayeva (Bulaevsky, Vysotensky ) & 3,74 \\
\hline Mamlyutsky & 3,86 \\
\hline Timiryazevsky & 3,22 \\
\hline Shal akyna (Sergievsky) & 3,79 \\
\hline
\end{tabular}


According to the data in Table 1, the greatest probabilistic information measure of diversity is characterized by the Yesil and Zhambyl districts located in the zone of wide development of the hollow-hilly-hryvnia relief. Due to the wide variety of relief, complex forest-steppe landscapes are formed on the territory of these areas, which determines the high coefficient. The lowest coefficient in the region -3.22 is noted in the Timiryazevsky district, where steppe landscapes of hollow-hilly plains prevail more homogeneous in their structure.

The steppe type is formed on flat loamy old-lake plains and is represented by 4 species, of which the landscapes of flat loamy old-lake plains with rich grass-red grass steppes on ordinary chernozems dominate.

The intrazonal landscapes include the Ishim River valleys, lake depressions. Essential importance in the overall structure of natural complexes belongs to the PTK of lake terraces and depressions with wormwood-grasses and halophyte-grass groupings on the solonets. Many forest-steppe and steppe landscapes are highly complicated by the salt complex.

The work on the study of the landscapes of the described territory for a number of years was carried out by leading specialists of the Department of Geography and Ecology of the North Kazakhstan State University. Associate Professor of the North Kazakhstan University, Candidate of Technical Sciences A.A. Gribsky proposed a scheme of landscape -typological zoning of the Ishim steppe, which includes the following typology of landscapes of the North Kazakhstan region. I would like to note that the specialists of the space monitoring laboratory have adopted this typology as a basis, which is currently supplemented by new scientific research:

- hryvnia - wavy western with forest - steppe soils;

- flat plain - zapadinny saline with large spots of malt;

- weakly undulating meadow-chernozem with islands of chernozems and malt;

- hollow - wavy - occidental chernozems of ordinary, meadow-chernozem and malt spots;

- hryvnia - lake with low-power chernozems, meadow-chernozem and salt lakes;

- slightly undulating with clay chernozems and hydromorphic saline soils;

- plain - westernized carbonate soils on loess-like sediments;

- plain - westernized carbonate soils on neogene clays;

- hollows of ancient runoff with saline soils;

- floodplain of the Ishim river with alluvial soils;

- riverine left-bank slope of ordinary chernozems on ancient alluvial deposits;

- riverine right-bank slope with eroded slopes;

- areas of the Kazakh melkosopochnik with underdeveloped and crushed soils.

Based on the above, it can be concluded that most researchers emphasize a clearly pronounced zonal differentiation of landscape types, which is associated with an increase in the amount of solar heat from north to south and a simultaneous decrease in atmospheric moisture, and the soil and vegetation cover changes according- 
ly. The close interrelation and interdependence of natural factors leads to the isolation of various types of landscapes from forest-steppe to steppe.

The purpose of this work is to assess the ecological condition of agricultural lands in the border territory of the North Kazakhstan region and identify the necessary measures to optimize the existing structure of land use.

\section{Material and methods}

We understand the landscape as an integral natural system with stable relationships and connections between components. Changing one component or a group of components inevitably entails changing the landscape as a whole. Such groups can be geological-geomorphological, climatic, hydrological, biological components. They influence each other to varying degrees. Some components and their properties constantly have a stronger influence on other components than they themselves fall under their influence [7].

However, as a basis for building a landscape structure, it is necessary to use indicators that are sufficiently resistant to various types of impact, and, above all, anthropogenic. According to many researchers, the relief of the earth's surface has this quality. The relief is closely connected with the lithology of the substrate, tectonics, climate, soil and vegetation cover. Therefore, in the allocation of geosystems of various ranks, the dominant role belongs to the geological and geomorphological basis, and the spatially developed system of relief forms corresponds to the morphological structure of the landscape.

To date, landscape and environmental studies are becoming a priority in Kazakhstan when creating the concept of rational nature management. They fully correspond to the concept of the republic's transition to sustainable development. In studies based on the principles of this concept, work has begun for various border regions of the republic to study the degree of change in natural-territorial complexes developing under the increasing pressure of the agricultural factor, to determine the possibility of their self-regulation and restoration, as well as to determine the directions and forms of post-technological development of natural-territorial complexes in order to implement environmental regulation.

Agriculture, when viewed from the point of view of environmental impact, does not belong to sectors of the economy with increased environmental hazard. At the same time, modern socio-economic conditions have led to a widespread decline in the culture of agriculture. Under these conditions, agriculture is one of the main factors of negative impact on soil fertility in large areas. To date, among all the environmental problems of the agro-industrial production of the republic, the tasks of preserving and restoring the fertility of agricultural landscapes, eliminating the negative consequences of anthropogenic impact on agricultural land, ensuring sustainable production of environmentally friendly products are highlighted.

The border territory of the North Kazakhstan region belongs to the zone of the Kazakh-Russian sector and covers an area of 46.4 thousand $\mathrm{km}^{2}$. This territory includes six border administrative districts and the territory of Petropavlovsk, and $89 \%$ of the entire border area is subject to agricultural impacts [8]. 
The territory under study is located in the zone of dry-steppe and steppe landscapes. Dry-steppe landscapes of relatively elevated plains prevail here. In recent decades, as a result of agricultural activity, there has been an increase in the processes of desertification of natural ecosystems, which has led to a decrease in productivity and degradation of agricultural land (Table 2).

Table 2 - The share of degraded lands in relation to the area of agricultural land and the area of the region, $\%$

\begin{tabular}{|l|c|}
\hline Degraded lands & Share of agricultural land area, \% \\
\hline degraded lands & 10,4 \\
\hline saline lands & 4,3 \\
\hline wind erosion & 3,7 \\
\hline
\end{tabular}

The agricultural impact on the land resources of this region increases every year. This leads to an increased risk of further development of erosive and deflationary processes, floods and excessive compaction of the soil.

The agricultural landscapes of the border North Kazakhstan region are mainly agricultural lands and pastures.

During the research work, it was revealed that in the border territory of the North Kazakhstan region, small agricultural formations, namely arable land, are being transferred to reserve lands. The potential danger is represented by negative anthropogenic processes, the development of water erosion, and deflation on soils of light mechanical composition. This is a consequence of the fact that puddling and reclamation works are not carried out on fallow lands. A comparative analysis of the modern structure of agricultural land has enabled us to assess the degree of balance of agricultural landscapes of the border North Kazakhstan region (Table 3).

The main agricultural landscapes in four border administrative districts of the North Kazakhstan region are agricultural (Mamlyutsky, Zhambylsky, Kyzylzharsky and M. Zhumabayev administrative districts) and in two border administrative districts - pasture (Akzharsky, Ualikhanov administrative districts).

The ploughing of the territory is one of the important indicators of the degree of anthropogenic transformation of the landscape of the border areas of the region (Fig. 1.).

In terms of plowing, the border territory of the North Kazakhstan region occupies one of the leading places in the Republic of Kazakhstan. The most plowed are the border areas - Mamlyutsky and M. Zhumabayev.

The ecological manifestation of degradation processes in the agricultural landscapes of the border area of the region is dehumification. This is expressed in a decrease in the humus content and entails a decrease in the reserves of nutrients in the soil, a violation of the balance of mineral and organic substances, a change in the structure of the soil and, as a consequence, the development of deflationary and erosive processes. 
Table 3 - Modern structure of lands in the border area of the region, $\%$

\begin{tabular}{|l|c|c|c|c|}
\hline $\begin{array}{c}\text { Administrative } \\
\text { unit }\end{array}$ & $\begin{array}{c}\text { The share of agri- } \\
\text { cultural land in the } \\
\text { total land area }\end{array}$ & $\begin{array}{c}\text { The share } \\
\text { of arable land } \\
\text { in the total area } \\
\text { of farmland }\end{array}$ & $\begin{array}{c}\text { The share } \\
\text { of hayfields } \\
\text { in the area } \\
\text { of farmland }\end{array}$ & $\begin{array}{c}\text { For pastures } \\
\text { in the area } \\
\text { of farmland }\end{array}$ \\
\hline Mamlyutsky & 79,2 & 55,1 & 2,2 & 42,5 \\
\hline Akzharsky & 91,4 & 33,1 & 0,3 & 52,2 \\
\hline Zhambylsky & 82,6 & 46,5 & 0,3 & 44,9 \\
\hline $\begin{array}{l}\text { named after M. } \\
\text { Zhumabayev }\end{array}$ & 81,6 & 72,1 & 0,01 & 27,8 \\
\hline Kyzylzharsky & 72,3 & 48,6 & 3,5 & 47,5 \\
\hline Ualikhanov & 86,0 & 22,2 & 0,3 & 69,6 \\
\hline
\end{tabular}

Thus, according to monitoring observations of the state of arable land in grain production areas in Northern Kazakhstan, conducted by the State Agricultural Research Center of the Ministry of Agriculture of the Republic of Kazakhstan, the process of humus loss is currently ongoing, and over the past ten years there has been a sharp decline - from $38.5 \%$ to $56.4 \%$ [9]. In general, in the border areas of the North Kazakhstan region, every second hectare of arable land contains less than 2.5-3.5\% humus and is characterized by low availability of mobile forms of nitrogen and phosphorus.

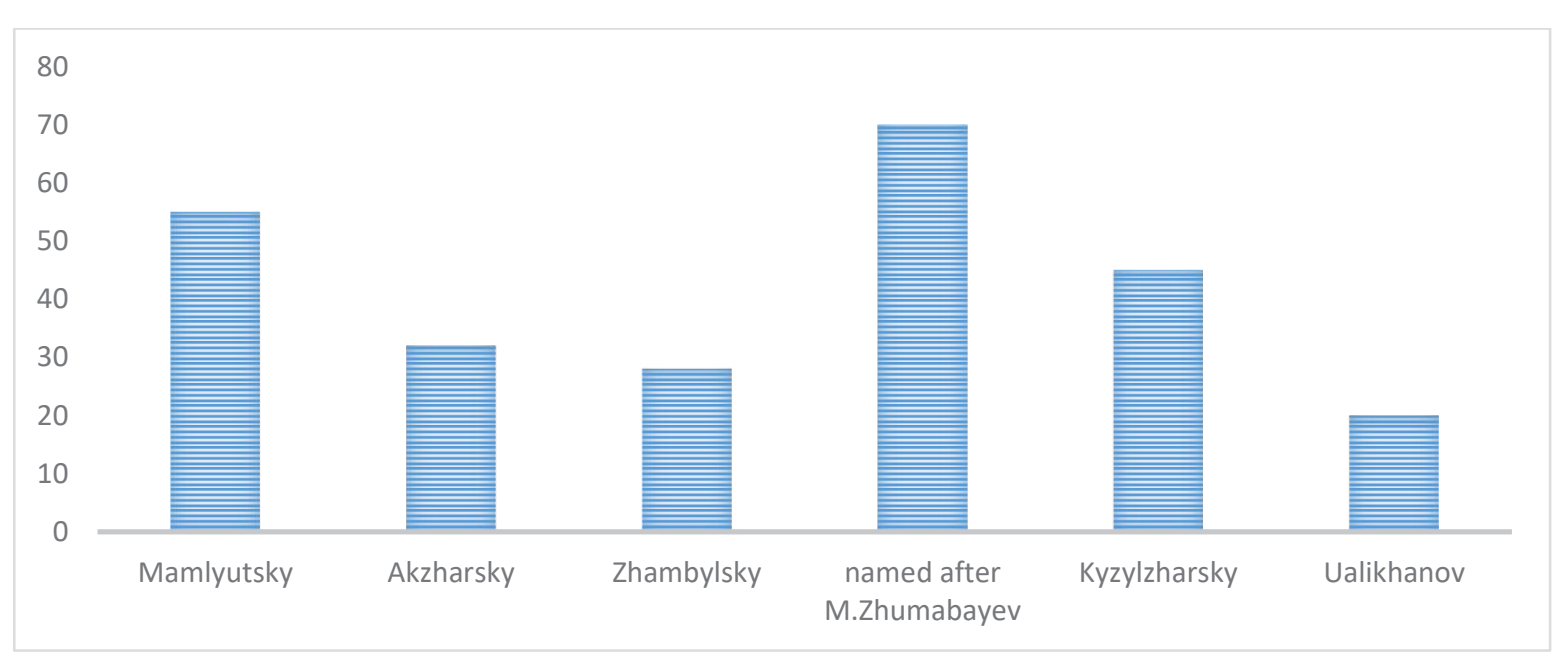

Figure 1 - Plowing of the border areas of the North Kazakhstan region, \%

\section{Results and discussion}

During the analysis of the ecological state of arable land in the border territory of the North Kazakhstan region, it was shown that about $65 \%$ of arable land is characterized by a favorable and satisfactory condition and is practically not complicated by negative signs. $17 \%$ of the arable land area is subject to salinization processes, and $14 \%$ is subject to erosion and waterlogging processes. In the Akzhar and Ualikhanov border administrative districts, the most intense ecological state of arable land is observed. The main causes of degradation of arable land are salinization and water erosion. 
On the territory of the border region, pasture agricultural landscapes amount to 1957.6 thousand hectares. The main part of pasture lands is located in the border administrative districts of Ualikhanov (770398 ha) and Akshar (384045 ha). Table 4 shows indicators characterizing the ecological state of pasture lands. Such indicators include: the degree of their degradation, cultural condition, water availability, on which the uniformity of the use of pasture lands depends.

The analysis of pasture lands of the border area showed that more than $35 \%$ of the total area of pastures are subject to varying degrees of degradation. The highest percentage of degraded pastures is in the Akzhar, Kyzylzhar and Mamlyut administrative districts. Ecological manifestations of anthropogenic transformation of pastures are the predominance of secondary vegetation groupings, deflation or water erosion.

Table 4 - Current state of pasture lands of the border territory of the North Kazakhstan region

\begin{tabular}{|l|l|c|c|c|}
\hline \multicolumn{1}{|c|}{$\begin{array}{c}\text { Administrative } \\
\text { region }\end{array}$} & \multicolumn{1}{|c|}{ The dominant group of pastures } & $\begin{array}{c}\text { Pasture } \\
\text { area, ha }\end{array}$ & Yield, c/ha & $\begin{array}{c}\text { Degraded } \\
\text { pastures, \% }\end{array}$ \\
\hline Kyzylzharsky & $\begin{array}{l}\text { mixed grass-cereals with birch- } \\
\text { aspen pegs }\end{array}$ & 211375 & 5,8 & 36,8 \\
\hline Mamlyutsky & mixed-grass cereals with pegs & 137951 & 6,0 & 41,6 \\
\hline Zhambylsky & wheatgrass-mixed herbs & 276861 & 5,0 & 28,6 \\
\hline $\begin{array}{l}\text { named after M. } \\
\text { Zhumabayev }\end{array}$ & wheatgrass-veiny & 177012 & 5,1 & 34,9 \\
\hline Akzharsky & $\begin{array}{l}\text { tipchakovo-wormwood- } \\
\text { raznotravnye }\end{array}$ & 384045 & 5,3 & 42,3 \\
\hline Ualikhanov & kovylno-raznotravnye & 770398 & 4,9 & 29,0 \\
\hline
\end{tabular}

In the studied border areas, virgin areas with indigenous vegetation have now been preserved in small spots around birch or birch-aspen spikes. On the preserved spots of meadow steppes there are: feather grass - feathery, red, narrow-leaved; tipchak; from meadow grass - creeping wheatgrass, boneless, narrow-leaved bluegrass, etc.; from various grasses - hemlock, mouse peas, zopnik, sage, sickle alfalfa. These pastures are used chaotically. The yield of pastures where indigenous vegetation has been preserved is $6-8 \mathrm{~kg} / \mathrm{ha}$ of dry weight.

Degradation of pasture agricultural landscapes in the border areas of the region is caused, first of all, by overgrazing on watered pastures and pastures around settlements where animals are kept year-round. Haphazard grazing of livestock in combination with high load, as well as increasing anthropogenic impact leads to severe degradation of pastures, which manifests itself in a decrease in productivity, loss of valuable forage species (cereals, sagebrush), replacing them with annual, weed and poisonous vegetation. In addition, in the pasture agricultural landscapes of the border areas of the region, there is an increase in the influence of negative anthropogenic processes, such as the churning of the upper soil layer and the development of deflation and erosion processes. In the border area, intensive grazing of livestock has a particularly negative effect on the state of pasture lands in the Akzhar, Mamlyut, Kyzylzhar, M. Zhumabayev districts. The load of livestock on the pastures of the border areas ranges from 14.5 to 123.5 heads per 100 agricultural lands (Table 5). 
Table 5 - Livestock load on pasture lands, in conventional units

\begin{tabular}{|l|c|c|c|c|c|}
\hline $\begin{array}{c}\text { Border } \\
\text { administrative districts }\end{array}$ & Cattle & Sheep & Horses & Pigs & $\begin{array}{c}\text { Livestock load per } \\
\text { 100 hectares } \\
\text { of farmland }\end{array}$ \\
\hline Akzharsky & 83326,7 & 12263,3 & 29552,0 & 14125,9 & 19,6 \\
\hline Zhambylsky & 99353,3 & 15676,7 & 31124,0 & 29031,9 & 30,3 \\
\hline M.Zhumabayeva & 138570,0 & 12223,3 & 37518,0 & 58574,2 & 60,8 \\
\hline Kyzylzharsky & 165781,7 & 9107,3 & 29542,0 & 67375,7 & 123,5 \\
\hline Mamlyutsky & 81433,3 & 7845,0 & 18704,0 & 29733,7 & 14,5 \\
\hline Ualikhanov & 89221,7 & 15269,7 & 43208,0 & 5425,9 & 35,9 \\
\hline Petropavlovsk & 7926,7 & 310,3 & 558,0 & 1708,1 & 56,4 \\
\hline $\begin{array}{l}\text { Total for the border } \\
\text { region }\end{array}$ & 665613,3 & 72695,7 & 190206,0 & 205975,4 & 45,1 \\
\hline
\end{tabular}

The ecological condition of pasture lands is greatly influenced by the degree and uniformity of their watering. The area of pastures watered by mine and tube wells within the border area has decreased from 39-51\% over the past 10 years [8] and currently their area does not exceed $30 \%$ of the pasture area. Moreover, the relatively satisfactory condition is noted in the Akzhar district, where the area of watered pastures is $35 \%$ and the most critical in the Ualikhanov border region, where the area of watered pastures is $15.2 \%$.

\section{Conclusions}

As a result of the assessment of the current ecological state of agricultural landscapes in the border territory of the North Kazakhstan region, we have identified five categories of their ecological state: favorable, satisfactory, moderately tense and tense.

The tense ecological state of agricultural lands is observed in forest-steppe and steppe landscapes, occupies an area of $31 \%$ of the territory of the border region (Fig. 2).

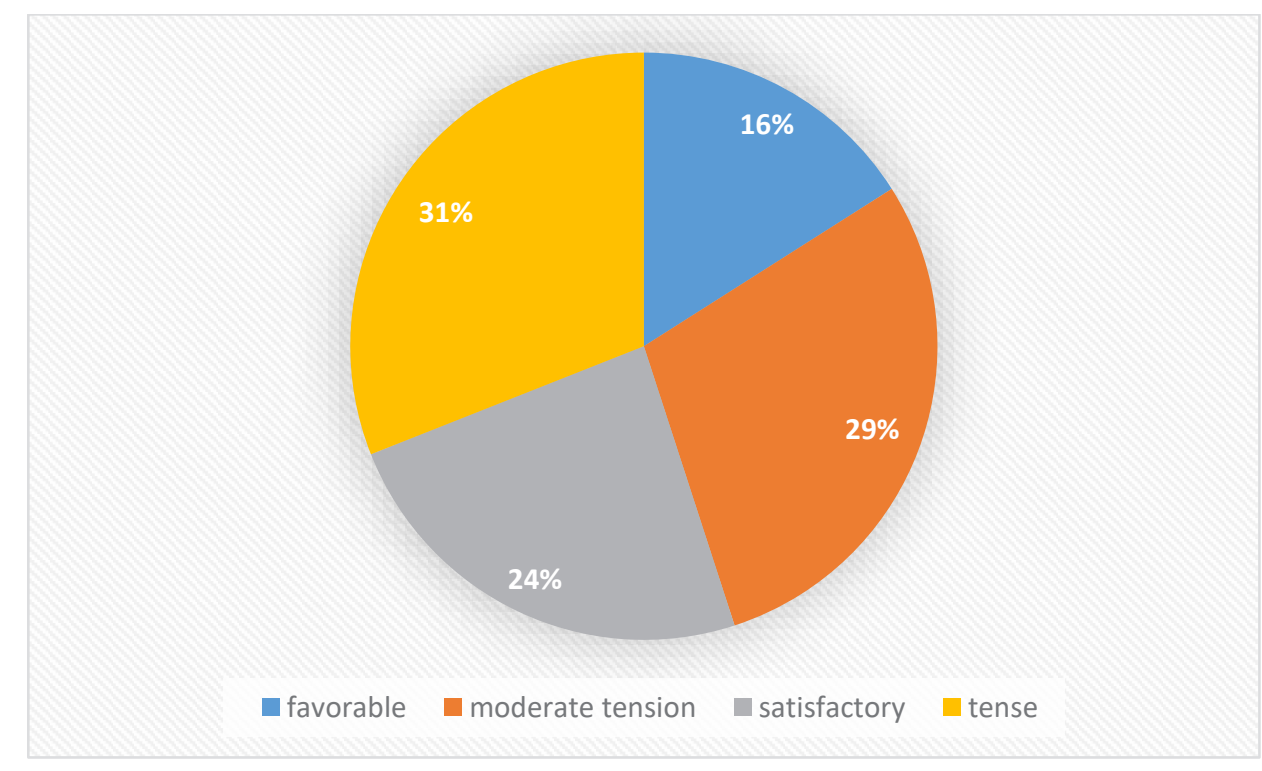

Figure 2 - Agricultural land areas by their ecological status, $\%$ 
Agricultural lands with a tense ecological state are available in all administrative districts of the studied region. This ecological condition is due to the following factors: high specific gravity of agricultural development (plowing of the territory); high level of pasture load of farms on agricultural landscapes; overgrazing of livestock by households within a radius of $5-15 \mathrm{~km}$ from settlements; the presence of cattle farms, poultry farms, warehouses for storing mineral fertilizers.

Agricultural lands with a moderately stressed state are concentrated mainly in the steppe and dry-steppe landscapes of the border region, occupy $13730.2 \mathrm{~km}^{2}$ $(29 \%)$.

Satisfactory ecological condition of agricultural lands is observed mainly in steppe and forest-steppe landscapes on an area of $11285.6 \mathrm{~km}^{2}(24 \%)$.

Favorable ecological condition of agricultural lands is observed in foreststeppe and steppe landscapes on an area of $7592.2 \mathrm{~km}^{2}(16 \%)$ in five border districts of the region (Mamlyutsky, Zhambylsky, named after M. Zhumabayev, Kyzylzharsky, Ualikhanov).

The assessment of the ecological condition of agricultural lands in the border territory of the North Kazakhstan region showed that the following measures are needed to optimize the existing structure of land use:

- reduction of the area of arable land to $45-50 \%$ of the land area, due to the withdrawal of deflated, low-yielding lands from arable land and transfer to haypasture lands, while simultaneously reducing the area of fields; lands subject to strong deflation processes must be sown with long-term drought-resistant grasses;

- increase in the area of protective forest belts in plowed areas up to 7-10\%. The optimal distance between the protective forest belts in the dry steppe, located perpendicular to the prevailing winds, is $200-300 \mathrm{~m}$, the width of the forest belts is 10-15 m (3-4 rows). In addition to arable land, it is necessary to create protective forest belts along the existing hydrographic network, around residential areas, water intakes, along roads;

- increasing the area of pastures and hayfields to at least $45 \%$ of the area of agricultural land and restoring grass cover due to radical improvement, tinning degraded areas, introduction of pasture rotations, reduction of pasture loads;

- irrigation of abandoned deposits with drought-resistant perennial grasses;

- creation of steppe reserves (dormant zones), occupying up to $10-15 \%$ of the total area of pasture plots;

- introduction of landscape-adaptive farming systems.

\section{References:}

1. Kolbovskiy E.Yu. Landshaftovedenie: ucheb. posobie dlya stud. [Landscape studies: manual for students]. Publishing Center "Academy». Moscow. 2006, 480. (in Russ.)

2. Golovanov A.I., Kozhanov E.S., Suharev Yu.I. Landshaftovedenie [Landscape Studies]. Kolos S, Moscow. 2005, 216. (in Russ.)

3. Armand D. L. Nauka o landshafte: (Osnovyi teorii i logiko-matematicheskie metodyi) [Landscape Science: (Fundamentals of theory and logical-mathematical methods)]. Myisl, Moscow. 1975, 288. (in Russ.) 
4. Beletskaya N. P., Fomin I. A., Mestnyie resursyi Severo-Kazahstanskoy oblast [Local resources of the North Kazakhstan region] Petropavlovsk: IPO SKGU named M. Kozyibaeva. 2012, 102. (in Russ.)

5. Ponomarenko A.S., Ruder V.P., Sartin S.A., Schukina V.N. O vozmozhnosti diversifikatsii zemel selskohozyaystvennogo naznacheniya SKO po sredstvam ispolzovaniya metodov DZZ [On the possibility of diversification of agricultural lands of the North Kazakhstan Region by means of using remote sensing methods]. Materialyi Mezhdunarodnoy nauchno-prakticheskoy konferentsii «Dostizheniya $i$ perspektivyi issledovaniy nebesnyih tel i Zemli: fundamentalnyie, prikladnyie i nauchno-metodicheskie aspektyi»= Materials of the International Scientific and Practical Conference "Achievements and prospects of research of celestial bodies and the Earth: fundamental, applied and scientific and methodological aspects». Petropavlovsk. 2014, 109-112. (in Russ.)

6. Ponomarenko A. S., Sartin S.A., Shokanova D.K., Schukina V.N. Metodika issledovaniya pochv na osnove ee spektralno otrazhatelnoy sposobnosti [Soil research methodology based on its spectral reflectivity]. Materialyi Mezhdunarodnoy nauchno-prakticheskoy konferentsii «Dostizheniya $i$ perspektivyi issledovaniy nebesnyih tel $i$ Zemli: fundamentalnyie, prikladnyie $i$ nauchno-metodicheskie aspektyi» = Materials of the International Scientific and Practical Conference "Achievements and prospects of research of celestial bodies and the Earth: fundamental, applied and scientific and methodological aspects». Petropavlovsk. 2014, 97-99. (in Russ.)

7. Sartin S.A., Fomin I.A. Vliyanie prirodnyih i antropogennyih faktorov na plodorodie pochv $v$ sootvetstvii s dannyimi aerokosmicheskogo monitoring [Influence of natural and anthropogenic factors on soil fertility according to aerospace monitoring data]. Materialyi Mezhdunarodnoy nauchno-prakticheskoy konferentsii "Dostizheniya i perspektivyi issledovaniy nebesnyih tel $i$ Zemli: fundamentalnyie, prikladnyie i nauchno-metodicheskie aspektyi $\rangle=$ Materials of the International Scientific and Practical Conference "Achievements and prospects of research of celestial bodies and the Earth: fundamental, applied and scientific and methodological aspects". Petropavlovsk. 2014, 129-133. (in Russ.)

8. Litvinenko M.Yu., Mahovyih I.A., Nemilostev N.D., Sartin S.A. Monitoring vyisotyi snezhnogo pokrova $v$ basseyne reke Esil (Ishim) [Monitoring of snow cover height in the Yesil River basin (Ishim)]. Materialyi Mezhdunarodnoy nauchno-prakticheskoy konferentsii «Dostizheniya i perspektivyi issledovaniy nebesnyih tel $i$ Zemli: fundamentalnyie, prikladnyie $i$ nauchnometodicheskie aspektyi» = Materials of the International Scientific and Practical Conference "Achievements and prospects of research of celestial bodies and the Earth: fundamental, applied and scientific and methodological aspects". Petropavlovsk. 2014, 101-105. (in Russ.)

9. Ashton M.S. et al. (Eds.) (2012) Managing Forest Carbon in a Changing Climate. ISBN: 9400722311.

10. Azevedo JC, Perera AH, Alice Pinto M. (eds.) (2014) Forest Landscapes and Global Change: Challenges for Research and Management. ISBN 978-1-4939-0952-0.

\title{
Н.Т. Шогелова ${ }^{1}$, С.А. Сартин
}

\author{
${ }^{1}$ Халықаралық білім беру корпорациясы (ҚазБСҚА кампусы), Алматы, Қазақстан \\ ${ }^{2}$ Манаш Қозыбаев атындағы Солтүстік Қазақстан университеті, Петропавл, Қазақстан
}

\section{Авторлар туралы ақпарат:}

Шогелова Назым Тулегеновна - техника ғылымдарының магистрі, профессор ассистенті, Халықаралық білім беру корпорациясы (ҚазБСҚА кампусы), Алматы, Қазақстан https://orcid.org/0000-0002-5220-1459, email: nazym-shogelova@mail.ru 
Сартин Сергей Александрович - физика-математика ғылымдарының кандидаты, физика кафедрасының меңгерушісі, Манаш Қозыбаев атындағы Солтүстік Қазақстан университеті, Петропавл, Қазақстан https://orcid.org/0000-0002-5637-3311, email: sartin78@mail.ru

\title{
СОЛТУСТІК ҚАЗАҚСТАН ОБЛЫСЫНЫН АУМАҒЫН ЗЕРТТЕУДЕ ЛАНДШАФТЫҚ-ГЕОХИМИЯЛЫҚ ТӘСІЛДІ ҚОЛДАНУ
}

\begin{abstract}
Аңдатпа. Мақалада Солтүстік Қазақстан обльсының шекаралас аумавындавы ауыл шаруашылывы мақсатындаzы жерлердің экологиялық жавдайын бавалау және жерді пайдаланудың қ̧олданыставы құрылымын оңтайландыру үшін қ̧ажетті іс-шараларды анықтау мәселелері құарастырылады. Зерттелген шекара аймагы құргақ дала және дала ландмафттары аймавында орналасқан, олардың арасында көтерілген жазықтарва құатысты құрzақ дала ландшафттары басым.

Түйін сөздер: ландшафт, Солтүстік Қазақсстан облысыь, ландшафтық-экологияльққ зерттеулер, құрвақ дала ландшафты, дала ландшафты.
\end{abstract}

\section{Н.Т. Шогелова ${ }^{1}$, С.А. Сартин ${ }^{2 *}$}

\footnotetext{
${ }^{1}$ Международная образовательная корпорация (кампус КазГАСА), Алматы, Казахстан ${ }^{2}$ Северо-Казахстанский университет имени Манаша Козыбаева, Петропавловск, Казахстан
}

\section{Информация об авторах:}

Шогелова Назым Тулегеновна - магистр технических наук, ассистент профессора, Международная образовательная корпорация (кампус КазГАСА), Алматы, Казахстан

https://orcid.org/0000-0002-5220-1459, e-mail: nazym-shogelova@mail.ru

Сартин Сергей Александрович - кандидат физико-математических наук, заведующий кафедрой физики, Северо-Казахстанский университет имени Манаша Козыбаева, Петропавловск, Казахстан https://orcid.org/0000-0002-5220-1459, e-mail: nazym-shogelova@mail.ru

\section{ПРИМЕНЕНИЕ ЛАНДШАФТНО-ГЕОХИМИЧЕСКОГО ПОДХОДА ПРИ ИЗУЧЕНИИ ТЕРРИТОРИИ СЕВЕРО-КАЗАХСТАНСКОЙ ОБЛАСТИ}

\footnotetext{
Аннотация. B статье рассматриваются вопросы оченки экологического состояния земель сельскохозяйственного назначения на приграничной территории Северо-Казахстанской области и выявление необходимых мероприятий для оптимизащии существующей структуры землепользования. Исследуемая приграничная территория расположена в зоне сухостепных и степных ландшафтов, среди которых преобладают сухостепные ландшафтыл относительно приподнятых равнин.

Ключевые слова: ландшафт, Северо-Казахстанская область, ландшафтно-экологические исследования, сухостепной ландшафт, степной ландшафт.
} 